QA:NA

DC\# 30462

$12106 / 01$

\title{
BIOSPHERE MODELING AND ANALYSES IN SUPPORT OF TOTAL SYSTEM PERFORMANCE ASSESSMENT
}

\author{
J.J. Tappen, M.A. Wasiolek, D.W. Wu, J.F. Schmitt \\ Bechtel SAIC Company, LLC. \\ 1180 Town Center Drive, Las Vegas, NV 89144 \\ A.J. Smith \\ Duke Engineering \& Services (USA) \\ 1180 Town Center Drive, Las Vegas, NV 89144
}

\begin{abstract}
The Nuclear Waste Policy Act of 1982 established the obligations of and the relationship between the U.S. Environmental Protection Agency (EPA), the U.S. Nuclear Regulatory Commission (NRC), and the U.S. Department of Energy (DOE) for the management and disposal of high-level radioactive wastes. In 1985, the EPA promulgated regulations that included a definition of performance assessment that did not consider potential dose to a member of the general public. This definition would influence the scope of activities conducted by DOE in support of the total system performance assessment program until 1995. The release of a National Academy of Sciences (NAS) report on the technical basis for a Yucca Mountain-specific standard provided the impetus for the DOE to initiate activities that would consider the attributes of the biosphere, i.e. that portion of the earth where living things, including man, exist and interact with the environment around them.

The evolution of NRC and EPA Yucca Mountain-specific regulations, originally proposed in 1999, was critical to the development and integration of biosphere modeling and analyses into the total system performance assessment program. These proposed regulations initially differed in the conceptual representation of the receptor of interest to be considered in assessing performance. The publication in 2001 of final regulations in which the NRC adopted standard will permit the continued improvement and refinement of biosphere modeling and analyses activities in support of assessment activities.
\end{abstract}

\section{Introduction}

In the analysis of dose consequences associated with a potential repository at Yucca Mountain Nevada, the biosphere model is the last link in a chain of models that assess and analyze the movement of radionuclides from the repository to man and the consequent doses. The biosphere can be defined as that portion of the earth that contains living organisms and in which ecosystems exist (1). The development of biosphere modeling and analyses as a component of the total system performance assessment activities for a potential repository at Yucca Mountain has been strongly influenced by 
the existing and proposed regulatory requirements. As the regulatory requirements evolved from generic rules and the multiple potential repository sites, through the transition period, to the Yucca Mountain site-specific rules, the biosphere modeling approach and analyses were changing from a simplified, peripheral study towards an integral and refined component of the total system performance assessment (TSPA). The following describes the evolution of biosphere-related analyses in response to regulatory change.

\section{Biosphere Modeling in Response to the Generic Rules}

The Congress of the United States, in the Nuclear Waste Policy Act (NWPA) of 1982 (2), established the relationship between the three major federal agencies involved in the management and disposal of spent nuclear fuel and high-level radioactive waste. These agencies, i.e. the EPA, the NRC, and the DOE, were given distinct but interrelated responsibilities. The EPA was required to establish the public health and safety standards for radionuclide releases from a repository. The NRC was required to promulgate regulations that would ensure that the construction, operation and closure of a repository would meet the standards established by EPA. The DOE was required to site, construct, operate and close a repository in accordance with the promulgated NRC regulations. After the responsibilities of the federal agencies were established by the NWPA, regulatory requirements for the disposal of high-level wastes were first developed in form of generic rules.

In June of 1983, the NRC issued technical criteria for the generic rule governing the disposal of high-level radioactive wastes in geologic repository at Title 10 Code of Federal Regulations (CFR) Part 60 (3). The technical criteria included the performance objectives, siting and design criteria for the geologic repository and the waste package, as well as performance confirmation requirements. The overall post-closure system performance objective for the repository stated in the rule $(\S 60.112)$ was to assure that the repository would meet the generally applicable environmental radiation protection standards established by EPA.

EPA followed the requirements of the NWPA by issuing in 1985 generic standards for the management, storage, and disposal of spent nuclear fuel (SNF), high-level waste (HLW), and transuranic (TRU) radioactive waste at Title 40 CFR Part 191 (4). These standards applied specifically to the management and disposal of material generated by activities regulated by the NRC and the disposal of similar materials generated by nuclear defense activities under the control of the DOE.

Subpart B of 40 CFR 191 established environmental standards for disposal of SNF, $\mathrm{HLW}$, and TRU wastes and for groundwater protection. The standards included a limit on amount of radioactivity that could be released to the accessible environment for a period of 10,000 years (containment requirements). Assurance requirements were established to provide confidence in the containment requirements. A limit on the annual dose received by a member of the general public for a period of 1,000 years after disposal was established (individual protection standard). And lastly, a release limit on the extent to 
which groundwater could be contaminated with radioactivity for a period of 1,000 years after disposal was established (standards for groundwater protection). The accessible environment was defined in the rule to encompass the atmosphere, land surface, surface water, oceans, and that portion of the lithosphere beyond the controlled area. Also, the rule defined analyses conducted to estimate cumulative releases to the accessible environment as performance assessment.

The individual protection standard required that if there was a release from the undisturbed disposal system within 1,000 years of disposal, then an analysis of the annual dose equivalent to any member of the general public was required. This standard specified that all potential pathways from the repository to the members of the general public must be considered and included an assumption that the individual drinks 2 liters of groundwater per day.

The early assessment of impacts associated with a potential repository at Yucca Mountain performed by DOE reflected the approach outlined in the generic rules. The goal of the 1986 assessment was to determine the likelihood that the potential waste disposal system could meet the existing EPA and NRC regulations (5). The system performance analysis included consideration of a waste package constructed of $304 \mathrm{~L}$ stainless steel, which had an expected lifetime ranging from 3,000 to 30,000 years. This range of expected waste package lifetime precluded any release of radioactive materials to the accessible environment within the performance timeframe of either the individual protection standard or the groundwater protection standard. As a result, an assessment of doses to members of the general public was not included in this preliminary postclosure performance analysis.

\section{Biosphere Modeling in a Period of Uncertainty}

In 1987, the disposal standards in 40 CFR Part 191 were remanded. In addition, the 1987 amendments to the NWPA selected Yucca Mountain, Nevada as the only potential site that DOE should characterize for a geologic repository (6). Although the disposal standards of 40 CFR 191 Subpart B were no longer applicable to the Yucca Mountain site, the DOE expected that the revised final standards, when released, would be very similar to what was originally promulgated. In an initial total system performance assessment (TSPA) for Yucca Mountain (7), the cumulative activity release of radionuclides to the accessible environment was used as a system performance measure, consistently with the containment requirements of the environmental standards in the remanded version of 40 CFR 191. In the assessment, the release point to the accessible environment was scenario dependent. For waterborne releases, the accessible environment was 5 kilometers $(\mathrm{km})$ from the repository. However, for human intrusion, basaltic igneous activities, and gaseous flow and transport, the release point was directly above the repository (7).

In 1992, the Yucca Mountain site was exempted from the EPA disposal standards by the Waste Isolation Pilot Plant Land Withdrawal Act (WIPP LWA) (8). It was expected that the performance period of 1,000 years in the remanded regulations would change to 
10,000 years when the new site-specific rules are promulgated. The potential extension of the performance period meant that the dose to members of the general public could no longer be excluded from consideration. This need to perform comprehensive analyses of the doses associated with the release of radionuclides from a potential repository was identified in "Preliminary Total-System Analysis of a potential High-level Nuclear Waste Repository at Yucca Mountain" (9).

In this preliminary analysis, the exposure scenarios considered a biosphere in which the receptor's lifestyles and environmental conditions were based on those around the Hanford site in southeastern Washington state. These scenarios were not fully representative of the area around Yucca Mountain. Although the biosphere was "generic" in nature, the results of the analyses indicated that the estimated doses were dependent on both the performance scenario (undisturbed or nominal performance vs. effects of disruptive events) and the exposure path (waterborne vs. surface contamination).

For the waterborne exposure path considered in this preliminary analysis, dose assessments were conducted for both multiple pathways and for water consumption only. The multiple pathway analyses assumed that the exposed individual lived on a farm $5 \mathrm{~km}$ down the hydrologic gradient from the repository. This farm provided $100 \%$ of the individual's dietary needs, and the individual drank 2 liters of contaminated water per day. It was also assumed that this individual spent approximately $50 \%$ of his/her time outdoors. Dietary intake values were based on those used for the average individual considered in the Hanford Defense Waste Environmental Impact Statement (9). For those analyses in which the aquifer was assumed to provide an insufficient volume of water to support a farm, the dose assessment considered only the consumption of 2 liters of water per day (9).

Analysis of the surface contamination path considered three receptors of interest: a driller, a post-intrusion resident who had a garden, and a post-intrusion resident who did not have a garden (9). In these analyses, each of the receptors was assumed to be located directly above the repository. The driller was assumed to inhale contaminated dust for 1 hour and to be exposed to contaminated soil for 40 hours. The characteristics of the postintrusion resident were based, in part, on data available from the Hanford Defense Waste Environmental Impact Statement. It was assumed that the garden produced only vegetables and fruits. Dietary intake values were $25 \%$ of the values used for the maximum individual considered in the Hanford Defense Waste Environmental Impact Statement (9).

\section{Development of Site-specific Standards for Yucca Mountain Site}

The Energy Policy Act of 1992 (10) directed the EPA to promulgate public health and safety radiation standards for Yucca Mountain that were designed to ensure the protection of public health from high-level waste that might be disposed of at a repository at Yucca Mountain, Nevada. The Act also directed the EPA to contract with the NAS to advise EPA on the technical bases for such a standard. 
In December 1993, EPA released the revised version of 40 CFR 191 Subpart B (11) containing the generic environmental radiation protection standards for disposal. Although the WIPP LWA exempted the Yucca Mountain site from these standards, the new rule was an indication of the requirements expected for the pending EPA standards for the Yucca Mountain site. The revised Subpart B still contained both a performance assessment requirement based on cumulative radionuclide release to the accessible environment and an individual protection requirement. However, the timeframe for the individual protection requirement was increased from 1,000 to 10,000 years. The individual protection requirement established an annual committed effective dose limit of 15 millirems. This dose was to be calculated using a methodology that was consistent with that used in Federal Guidance Reports No. 11 \& 12.

Shortly after the release of the revised EPA standards, a portion of the "generic" biosphere was considered in a subsequent TSPA (12). In this evaluation of repository performance, commonly referred to as TSPA -1993, the dose from the aqueous pathways was calculated using dose conversion factors that were based on several sources including the work performed by Eslinger et. al in 1993 (2). The dose was calculated for a receptor who obtained all of his/her drinking and irrigation water from contaminated groundwater, and consumed only locally produced foods. Once more, the analyses were based on the environment and the lifestyles of the people around the Hanford site.

Because a total system performance assessment process is an iterative process in which refinements and improvements to facility design and/or knowledge of other aspeçts under consideration are periodically incorporated into the assessment, a revision to TSPA-1993 was conducted and released in 1995 (13). In this revision, the calculated individual peak dose was based on the assumption that the receptor of interest received the dose from drinking only contaminated water. This individual was assumed to be located at the point on the accessible environment boundary $(5 \mathrm{~km})$ that corresponded to the peak radionuclide concentration in the groundwater. Dose conversion factors from Federal Guidance Report 11 were used in this analysis (13).

In late 1995, the NAS released their recommendations and technical bases for a Yucca Mountain-specific standard that protected the health and safety of the general public (14). The standard recommended by the NAS was an individual health-risk standard that was based, in part, on the critical group approach defined by the International Commission on Radiation Protection (ICRP) (14). In order to demonstrate compliance with the standard, NAS indicated that it would be necessary to calculate the distribution of doses associated with the radionuclide releases from Yucca Mountain. In estimating this dose, the NAS stated that the identification of the major pathways from a repository at Yucca Mountain to humans was required (14). Consequently, it would be necessary to consider radionuclide concentration in those portions of the biosphere that were accessible to humans, as well as the dietary habits and lifestyles of the population that may be exposed. The NAS also concluded that it is important to quantitatively consider the uncertainties associated with the modeling process in the assessment of performance of a repository against a risk-based standard. 
In identifying the potentially exposed population (the critical group), the NAS suggested that such a group would live in the near vicinity of Yucca Mountain and could be exposed by the use of contaminated groundwater (14). The NAS also concurred with the ICRP recommendation that defining the characteristics of the critical group should be done using current knowledge (14).

As a result of the NAS recommendations, and in response to existing regulatory requirements for dose assessment, a program was developed in late 1996 to collect data that would support the analysis, evaluation, and modeling of the transport of radionuclides through the environment at Yucca Mountain to the exposed population and the resulting doses (15). This program was intended to develop and use site-specific and/or analog data to generate biosphere dose conversion factors (BDCF). The BDCFs would support the assessment of dose to receptor of interest during the pre-closure and post-closure phases of a repository operation. BDCFs represent the dose from annual exposure to radionuclide in the environment and were to be developed for each radionuclide of interest in groundwater assuming an initial unit activity concentration in water. Because of the linearity of the system, the expected annual dose could then be calculated by multiplying the expected radionuclide concentration in groundwater (picoCurie per liter [pCi/l]) by the corresponding BDCF (rem/yr per pCi/l). The resulting dose for each radionuclide would then be summed to yield the expected annual dose.

The program also included a survey to collect dietary and lifestyle information on adults living within an $80 \mathrm{~km}$ radius of Yucca Mountain. The goals of this survey were to collect data on the annual consumption of groundwater and locally produced foodstuffs, socioeconomic information, and to link these data with geographic location to support identification of potentially exposed groups (16). The results of the survey found that the residents in Amargosa Valley were more likely to consume local groundwater and locally produced crops and livestock watered with local groundwater than the residents of Beatty, Pahrump or Indian Springs. The information collected during the survey was subsequently used to develop the BDCFs for the next TSPA, as described below.

The U.S. Congress, in the Energy and Water Development Appropriations Act of 1997, directed the DOE to include a TSPA in the Viability Assessment (VA) for a repository at Yucca Mountain, Nevada (17). Given the lack of any Yucca Mountain-specific regulatory requirements or guidance, and assuming that future EPA regulations would follow the NAS recommendation, the DOE integrated the biosphere modeling and analyses activities into the TSPA program.

As part of that comprehensive biosphere modeling program to support TSPA-VA, as well as other assessment activities, available environmental radiological assessment codes were reviewed (18). The GENII-S was selected as the implementing code to support the first Yucca Mountain-specific biosphere model in assessment of the radionuclide movement through the environment to the receptor of interest. This code which is based on the GENII code originally developed for the Hanford Reservation, was developed for assessment activities associated with the Waste Isolation Pilot Plant. GENII-S was 
selected on the bases of its capabilities to consider multiple radionuclide pathways through the environment to man and to perform stochastic sampling of input parameter values.

The conceptual biosphere model used to support TSPA-VA considered a receptor of interest that was an adult, who lived year round at the location of the nearest actual resident, i.e. approximately $20 \mathrm{~km}$ from the potential repository location, and who had dietary and lifestyle characteristics of the average resident of Amargosa Valley. Environmental conditions, e.g., rainfall and temperature, at this location were consistent with the current arid and semi-arid conditions around Yucca Mountain. Based on its location down the hydrologic gradient from the potential repository location, and the results of the consumption survey, the biosphere model considered that Amargosa Valley would contain those individuals most likely to receive the highest doses.

In support of TSPA-VA, biosphere modeling activities considered two performance scenarios, a nominal or base case and a disruptive case (19). Under the base case, radionuclides from the repository were transported to the biosphere via groundwater. For the disruptive case, radionuclides were introduced into the biosphere, as a result of a volcanic eruption, and subsequently transported via atmospheric processes and deposited at the location $20 \mathrm{~km}$ from the repository.

For the base case, the biosphere model developed BDCF for three receptors of interest living under current climatic conditions: a subsistence farmer, a resident farmer, and the average Amargosa Valley resident. The dietary characteristics of these receptors were based on the results of the 1997 food consumption survey. The subsistence farmer was assumed to obtain $100 \%$ of his food from local sources, to drink, on the average, 2.4 liters of local well water per day, and spend more than $70 \%$ of the year outdoors. The resident farmer was also assumed to drink, on the average, 2.4 liters of well water per day. However, only $50 \%$ of the food consumed by the resident farmer came from local sources, and only $33 \%$ of the year was spent outdoors. The consumption rates of locally produced food and water for the average Amargosa Valley resident were less than those for either type of farmer receptor. In order to assess, on a preliminary basis, the potential effects of climate change, additional BDCF were developed for twice and three times current precipitation conditions for each receptor.

As part of the assessment of the effects of disruptive event, i.e., eruption of contaminated magma from a volcano passing through the repository, biosphere modeling activities focused on developing BDCF for two scenarios. In the first scenario, the receptor of interest was assumed to be exposed to a passing cloud of contaminated ash for a period of one hour. The receptor was assumed to receive a dose as a result of inhaling contaminated ash and being submerged in the cloud of ash. BDCF were calculated for a unit concentration of each radionuclide in air and for an exposure duration of one hour. Exposure to ash via ingestion of contaminated foods or water was not included as the groundwater was considered to be uncontaminated. 
For the second scenario, which considered the use of land covered with contaminated ash, biosphere analyses again considered multiple pathways to a receptor who was representative of the average Amargosa Valley adult resident. The analyses considered contamination, as the result of the ash fall, of a six-inch root zone of crops grown for both human and animal consumption. In addition, the analyses also considered ingestion and inhalation of contaminated soil and external exposure from radionuclides in the ash. Individual radionuclide $\mathrm{BDCF}$ were calculated assuming deposition of $1 \mathrm{pCi}$ per square meter $\left(\mathrm{pCi} / \mathrm{m}^{2}\right)$.

\section{Biosphere Modeling Activities in response to EPA and NRC Proposed and Final Rules for Yucca Mountain}

On February 22, 1999, the NRC released its proposed rule "Disposal of High-level Radioactive Wastes in a Proposed Geological Repository at Yucca Mountain, Nevada." (20). In this proposed rule, NRC introduced the concepts of reference biosphere and critical group, provided regulatory requirements for each one and tied, for the first time, the requirements for performance assessment specifically to the characteristics of both a reference biosphere and a critical group. Performance assessment was required to demonstrate that the expected annual dose to the average member of the critical group would not exceed 25 mrem total effective dose equivalent for a period of 10,000 years after permanent closure (20).

Under Section 63.115 of the proposed rule, the reference biosphere was required to be consistent with arid or semi-arid conditions and contain features, events, and processes consistent with current knowledge of the conditions around Yucca Mountain. Consideration of changes in the reference biosphere was specifically limited to climatic changes, as indicated in the geologic record, and geologic changes consistent with current knowledge of natural processes.

The critical group was required to reside within a farming community of 100 people who are located approximately $20 \mathrm{~km}$ south of the underground facility. This farming community was expected to exhibit characteristics and lifestyles consistent with current conditions. The members of the critical group were expected to exhibit those characteristics and behaviors that would result in the highest expected annual dose. The average member of the critical group was to be used for a compliance demonstration assessment.

At approximately the same time the NRC proposed regulations were released, the DOE implemented a program to support the TSPA for Site Recommendation (TSPA-SR). This program consisted of a series of Process Model Reports (PMRs) and associated Analysis and Model Reports (AMRs) were to provide the technical justification and traceability for models and data used. The release of the NRC's proposed regulations provided the impetus to further focus and integrate biosphere modeling activities into the overall TSPA model. 
In August 1999, EPA released its proposed rule "Environmental Radiation Protection Standards for Yucca Mountain, Nevada" (21). In this proposed rule, EPA introduced, for the first time relative to the disposal of spent fuel and high-level waste, the concept of the reasonably maximally exposed individual (RMEI) as the receptor of interest for whom the individual protection standard applied. In addition, EPA defined performance assessment as an analysis that included calculation of the estimated annual committed effective dose equivalent to the RMEI. With the publication of the proposed rules from $\mathrm{EPA}$ and $\mathrm{NRC}$, the regulatory linkage between performance assessment and the biosphere was finally established.

In support of the TSPA-SR (22), biosphere modeling activities were revised and expanded from what was done to support TSPA-VA to activities that would be more consistent with the proposed NRC regulations. In the TSPA-SR analyses, the average member of the critical group was considered representative of a bounding case RMEI. Although the performance scenarios considered, i.e., the nominal performance and the igneous disruption performance, remained essentially unchanged, the way in which the receptor of interest was developed and the way climate change was evaluated changed significantly.

Specifically for the nominal case, the receptor of interest was changed from the average Amargosa Valley resident to the average member of a critical group that resided within the general Amargosa Valley population. This critical group consists of full time residents of Amargosa Valley who are involved in agricultural activities during a significant portion of the day. In addition, these individuals spend some part of the day outdoors in recreational or leisure activities, consume more than 2 liters per day of local groundwater, and consume some locally grown foods, of which a portion is grown in their own garden. The lifestyle and dietary characteristics of this group were based, in part, on the data collected in 1997.

For TSPA-SR (22), the biosphere analysis of the impacts of climate evolution was changed from the simplistic analyses done to support TSPA-VA to a more comprehensive analysis of the impacts of a cooler, wetter, glacial-transition climate that might occur during the regulatory compliance period. For this analysis Spokane, Washington was chosen as the analog site to be considered based on the current environment conditions in Spokane and those postulated to have existed at Yucca Mountain based on the geologic record. The analysis of climate change not only considered the effect on irrigation practices but also the effects on such parameters as crop growing times, crop yields, and dietary characteristics of the receptor of interest.

The biosphere analyses in support of the disruptive event scenario in TSPA-SR were expanded and refined to consider three different human exposure scenarios. Each of these scenarios corresponded to a different phase during and following the volcanic eruption. The first scenario considered the passage of the ash cloud over the location of the critical group and analyzed only the inhalation of the airborne contaminated ash. The transition phase, the second scenario analyzed was characterized by the consideration of the dose from volcanic ash deposited as a result of the passage of the ash cloud and the dose from 
ash resuspended as a result of natural and human activities. This resuspended ash then contributes to the exposure of members of the critical via multiple pathways.

Specifically, this ash was inhaled or subsequently redeposited on crops that are either consumed directly by man or used as feed for livestock that are then consumed by man. In these analyses, the deposited ash was not mixed into the soil and provided a source of contamination to the edible portion of the crops via the soil to root pathway. For the third scenario, the steady-state phase, biosphere analyses evaluated the consequences of the environment returning to pre-eruption conditions. In this scenario, the deposited contaminated ash was uniformly incorporated into the soil and environmental conditions were essentially identical to those considered for the nominal case.

In September 2000, biosphere modeling and analysis activities in support of TSPA-SR underwent a peer review by an International Review Team (IRT) assembled by the International Atomic Energy Agency (IAEA) (23). The objective of the review was to provide an evaluation of biosphere activities based on available international standards. In their review, the IRT acknowledged that the biosphere analyses and modeling activities conducted for a potential repository at Yucca Mountain were conditioned by and focused on the requirements of pending EPA and NRC regulations. As a result of the review, the IRT put forth two types of recommendations. The first group is meant to improve biosphere modeling activities while remaining focused on regulatory requirements. The second group of recommendations is focused on improving the confidence of stakeholders, and on bringing the biosphere activities closer to consistency with international guidance and practice (23). The DOE analyzed some of these recommendations in subsequent assessments while others are currently under review and evaluation.

Following the release of the proposed regulations from EPA and NRC and publication of the TSPA-SR (22), modeling activities entered the next iteration. These activities, including those relating to the biosphere, focused on the incorporating data that were not available at the time the initial TSPA-SR analyses were conducted. In addition to considering new data, these analyses also considered the impact of alternative repository and waste package designs, and model/data uncertainties on the long-term performance of the potential repository. Although the biosphere model and analyses were not affected by the alternative repository and waste package design, some improvements were incorporated into the model (24).

For biosphere modeling, the changes included the development of behavioral factors which allow the annual dose to be calculated based on a pre-defined behavior characteristics, selection of more appropriate mass loading and resuspension factors, especially for the volcanic release, and identification of climate dependent irrigation rates and durations. These refinements resulted in the development of revised BDCF for both the nominal scenario and the igneous disruption scenarios previously considered which were used to support the TSPA model documented in the "FY 01 Supplemental Science and Performance Analyses" (25). In addition, the document included evaluation of the impact of the previously unquantified uncertainties on the long-term performance of the potential repository. The uncertainties in the biosphere conceptual and mathematical 
model, as well as parameter values selected, were identified and the impact of selected uncertainties on the outcome of the biosphere modeling was evaluated.

On June 13, 2001, EPA issued the final rule containing public health and environmental radiation protection standards for Yucca Mountain at 40 CFR Part 197 (26). Nearly six months later, on November 2, 2001, NRC issued its final version of licensing criteria for disposal of SNF and HLW in the geologic repository at Yucca Mountain at 10 CFR Part 63 (27). With respect to the requirements necessary for analyses of the movement of radionuclides through the biosphere to man, the rules are consistent.

The subsequent biosphere analyses developed the BDCF for the RMEI based on both the ICRP-30 and ICRP-72 dosimetric methods. The set of BDCF based on ICRP-30 were used in the auxiliary TSPA analyses supporting the SR documentation while those based on ICRP-72 were used to support the Final Environmental Impact Statement (FEIS) for Yucca Mountain. (28).

\section{Conclusion}

The development of biosphere modeling activities in support of the total system performance assessment program was dependent on the evolution of regulatory environment. As the regulatory requirements for performance assessment evolved from an assessment of cumulative activity release to expected annual dose, the complexity of and the integration of the biosphere model into assessment activities also increased.

\section{References}

1) J.E. Till and H.R. Meyer, 1983. "Radiological Assessment, A Textbook on Environmental Dose Analysis." NUREG/CR-3332. Washington, D.C.: U.S. Nuclear Regulatory Commission.

2) Nuclear Waste Policy Act of 1982. 42 U.S.C. 10101 et seq..

3) 48 FR 28194. 10 CFR Part 60 Disposal of High-Level Radioactive Wastes in Geologic Repositories Technical Criteria.

4) 50 FR 38066. Protection of Environment: Environmental Standards for the Management and Disposal of Spent Nuclear Fuel, High-Level and Transuranic Radioactive Wastes; Final Rule.

5) DOE (U.S. Department of Energy) 1986. "Environmental Assessment Yucca Mountain Site, Nevada Research and Development Area, Nevada." DOE/RW-0073. Volume Three. Washington, D.C.: U.S. Department of Energy, Office of Civilian Radioactive Waste Management.

6) Nuclear Waste Policy Amendments Act of 1987. Public Law No. 100-203. 101 Stat. 1330. 
7) R.W. Barnard; M.L. Wilson; H.A. Dockery; J.H. Gauthier; P.G. Kaplan; R.R. Eaton;

F.W. Bingham; and T.H. Robey 1992. "TSPA 1991: An Initial Total-System

Performance Assessment for Yucca Mountain." SAND91-2795. Albuquerque, New

Mexico: Sandia National Laboratories.

8) Waste Isolation Pilot Plant Land Withdrawal Act. Public Law No. 102-579. 106 Stat. 4777.

9) P.W. Eslinger; L.A. Doremus; D.W. Engel; T.B. Miley; M.T. Murphy; W.E. Nichols; M.D. White; D.W. Langford; and S.J. Ouderkirk, 1993. "Preliminary Total-System Analysis of a Potential High-Level Nuclear Waste Repository at Yucca Mountain." PNL8444. Richland, Washington: Pacific Northwest Laboratory.

10) Energy Policy Act of 1992. 42 U.S.C. 13201 et seq

11) 58 FR 66398 (1993). 40 CFR Part 191: Environmental Radiation Protection Standards for the Management and Disposal of Spent Nuclear Fuel, High-Level and Transuranic Radioactive Wastes; Final Rule.

12) CRWMS M\&O 1994. "Total System Performance Assessment - 1993: An Evaluation of the Potential Yucca Mountain Repository." B00000000-01717-2200-00099 REV 01. Las Vegas, Nevada

13) CRWMS M\&O 1995. "Total System Performance Assessment - 1995: An Evaluation of the Potential Yucca Mountain Repository.” B00000000-01717-2200-00136 REV 01. Las Vegas, Nevada: CRWMS M\&O.

14) National Research Council 1995. "Technical Bases for Yucca Mountain Standards." Washington, D.C.: National Academy Press.

15) CRWMS M\&O 1996. "Scientific Investigation Implementation Package for Developing Biosphere Dose Conversion Factors." B00000000-01717-4600-00073 REV 00. Las Vegas, Nevada: CRWMS M\&O.

16) CRWMS M\&O 1997. "The 1997 'Biosphere" Food Consumption Survey Summary Findings and Technical Documentation." Las Vegas, Nevada

17) Energy and Water Development Appropriations Act, 1997. Public Law No. 104-206. 110 Stat. 2984.

18) M.W. Harris, 1997. "Recommendation of Models to be Used in the Biosphere Modeling Effort." Letter from M.W. Harris (CRWMS M\&O) to W.R. Dixon (DOE/YMSCO), July 8, 1997, LV.ESR.CHT.07/97-125, with attachment. 
19) CRWMS M\&O 1998. "Biosphere." Chapter 9 of Total System Performance Assessment-Viability Assessment (TSPA-VA) Analyses Technical Basis Document. B00000000-01717-4301-00009 REV 01. Las Vegas, Nevada

20) 64 FR 8640. Disposal of High-Level Radioactive Wastes in a Proposed Geologic Repository at Yucca Mountain, Nevada. Proposed Rule 10 CFR Part 63.

21) 64 FR 46976. Environmental Radiation Protection Standards for Yucca Mountain, Nevada. Proposed rule 40 CFR Part 197.

22) CRWMS M\&O 2000. "Total System Performance Assessment for the Site Recommendation.” TDR-WIS-PA-000001 REV 00 ICN 01. Las Vegas, Nevada

23) IAEA (International Atomic Energy Agency) 2001. “An International Peer Review of the Biosphere Modelling Programme of the US Department of Energy's Yucca Mountain Site Characterization Project, Report of the IAEA International Review Team." Vienna, Austria: International Atomic Energy Agency.

24) DOE (U.S. Department of Energy) 2001. "Yucca Mountain Science and Engineering Report." DOE/RW-0539. Washington, D.C.]: U.S. Department of Energy, Office of Civilian Radioactive Waste Management.

25) BSC (Bechtel SAIC Company) 2001. "FY 01 Supplemental Science and Performance Analyses, Volume 1: Scientific Bases and Analyses." TDR-MGR-MD-000007 REV 00 ICN 01. Las Vegas, Nevada

26) 66 FR 32074. 40 CFR Part 197, Public Health and Environmental Radiation Protection Standards for Yucca Mountain, NV; Final Rule.

27) 66 FR 55732. 10 CFR Parts 2, 19, 20, 21, etc, Disposal of High-level Radioactive Wastes in a Proposed Geologic Repository at Yucca Mountain, Nevada; Final Rule.

28) BSC (Bechtel SAIC Company) 2001. "Total System Performance Assessment Analyses for Disposal of Commercial and DOE Waste Inventories at Yucca Mountain Input to Final Environmental Impact Statement and Site Suitability Evaluation." REV 00 ICN 01. Las Vegas, Nevada 